\title{
Применение ингибиторов mTOR как подход к снижению негативного влияния глюкокортикоидов на регуляцию межклеточных контактов клеток рака молочной железы
}

\author{
Дёмина Д.В. ${ }^{1 *}$, Жидкова Е.М. ${ }^{2}$, Лылова Е.С. ${ }^{2}$, Григорьева Д.Д. ${ }^{2}$ \\ ${ }^{1}$ ФГБУ ВО «МИРЭА - Российский технологический университет», Москва, Россия \\ ${ }^{2}$ ФГБУ «НМИЦ онкологии им. Н.Н. Блохина» Минздрава России, Москва, Россия \\ *99.dasha.demina@mail.ru
}

Ключевые слова: рак молочной железы, глюкокортикоиды, mTOR, рапамицин, LY294002

Мотивация и цель: Глюкокортикоиды (ГК) широко применяются в клинической практике, в том числе для снижения побочных эффектов химиопрепаратов при терапии солидных опухолей. Однако их применение в качестве адъювантов при терапии рака молочной железы (РМЖ), может приводить к разобщению межклеточных контактов и повышенной вероятности метастазирования [1]. Течение РМЖ часто сопровождается нарушением сигнального пути mTOR. Ранее было показано, что применение ингибиторов mTOR в комбинации с ГК снижает побочные эффекты системного применения ГК в отношении опухолей кроветворной системы [2]. В отношении солидных опухолей подобных исследований ранее не проводилось. Цель работы - изучение влияния ингибиторов $\mathrm{mTOR}$ индивидуально и в комбинации с ГК на уровень экспрессии ряда генов, отвечающих за формирование межклеточных контактов на моделях РМЖ in vitro. Memodbl $u$ алгоритмы: В работе были использованы клеточные линии люминального (MCF-7) и базального (MDA-MB-231) PMЖ, ингибиторы mTOR рапамицин, LY294002 (0.1 мкM) и ГК дексаметазон (100 мкМ). Клетки рассевали в 6-луночные планшеты по 500 тыс. клеток, после прикрепления к подложке вносили исследуемые ингибиторы $\mathrm{mTOR}$, инкубировали 4 ч, а затем в часть лунок вносили ГК. Уровни экспрессии ряда ГК-зависимых генов, связанных с формированием межклеточных адгезий клеток РМЖ (ICAMI, CDH1, $F I B L 1, S K 1, I L 1 B, R H O B, I L 6)$, определяли методом ПЦР в реальном времени через 24 ч после обработки ГК. Результаты: Было показано, что ингибиторы mTOR и ГК снижают экспрессию е-кадхерина $(C D H 1)$, однако при применении рапамицина совместно с ГК наблюдается повышение экспрессии $C D H 1$ в клетках базального и люминального РМЖ. В то же время ингибиторы mTOR ингибируют действие ГК на экспрессию генов ICAM1, FIBL1 и SK1 в клетках PMЖ. Bblводы: Ингибиторы mTOR способны регулировать экспрессию генов, связанных с межклеточными взаимодействиями и миграцией опухолевых клеток, понижая метастатический потенциал клеток РМЖ. При этом они могут нивелировать действие ГК на ряд генов, связанных с активацией метастазирования РМЖ. Таким образом, применение ингибиторов mTOR в комбинации с ГК может стать подходом к снижению побочных эффектов ГК при терапии РМЖ. Финансовая поддержка: Работа выполнена при финансовой поддержке Российского научного фонда (грант № 17-75-20124).

\section{Список литературь}

1. Zhidkova E.M. et al. A brief overview of the paradoxical role of glucocorticoids in breast cancer. Breast Cancer: Basic Clinical Research. 2020;14:1178223420974667.

2. Lesovaya E.A. et al. A novel approach to safer glucocorticoid receptor-targeted anti-lymphoma therapy via REDD1 (regulated in development and DNA damage 1) inhibition. Molecular Cancer Therapeutics. 2020;19(9):1898-1908. 